\title{
Potential inhibitors to recovery of Acropora palmata populations in St. John, US Virgin Islands
}

\author{
Rikki Grober-Dunsmore $^{1,2,3, *}$, Victor Bonito ${ }^{1}$, Thomas K. Frazer ${ }^{1}$ \\ ${ }^{1}$ Department of Fisheries and Aquatic Sciences, University of Florida, 7922 NW 71st Street, Gainesville, Florida 32653, USA \\ ${ }^{2}$ Florida Integrated Science Center, Biological Resources Division, US Geological Survey, 7920 NW 71 st Street, Gainesville, \\ Florida 32653, USA
}

${ }^{3}$ Present address: Southwest Fisheries Science Center, National Marine Protected Areas Center, 110 Shaffer Road, Santa Cruz, California 95060, USA

\begin{abstract}
Populations of Acropora palmata in the Caribbean were decimated in the 1970 s and 1980s, with little apparent signs of recovery until the late 1990s. Here, we document an increase in A. palmata colonies between 2001 and 2003 at 8 of 11 monitoring sites in waters adjacent to the island of St. John, US Virgin Islands. The shallow waters along the NW coast of the island exhibited the greatest increase in colony abundance, perhaps due to greater larval supply and/or conditions that favor settlement and subsequent survivorship. Of concern, however, is the lack of survival of large colonies (at all sites), which are most frequently affected by stressors (e.g. Coralliophila abbreviata, damselfishes, active disease) and are most likely to be remnants (colonies with discontinuous, living coral-tissue over an existing coral framework). Predation by $C$. abbreviata and active coral disease may directly contribute to the development of these remnant colonies. In addition, we recorded damage to colonies attributed to damselfishes and raise the possibility that these territorial reefinhabitants act as vectors in the transmission of coral disease. While the incidence of disease around St. John is generally low, it may persist as a ubiquitous, chronic stress. Finally, because stressors are more prevalent on large colonies and in high-density stands, they have the potential to inhibit the recovery of $A$. palmata populations to their historic condition.
\end{abstract}

KEY WORDS: Coral reefs $\cdot$ Elkhorn coral $\cdot$ Corallivorous snails $\cdot$ Resheeting $\cdot$ Recruitment

\section{INTRODUCTION}

Coral-reef ecosystems worldwide are degraded (Pandolfi et al. 2003) due, in large part, to chronic, multiple stressors that have resulted in a marked decline in the abundance and diversity of reef organisms (Hughes 1994, Jackson et al. 2001). Although this degradation began centuries ago (see Jackson et al. 2001, Pandolfi et al. 2003), recent increases in the spectrum, frequency and intensity of disturbance events have dramatically altered coral-reef community structure (Hughes \& Connell 1999) and potentially reduced ecosystem resilience (Nyström et al. 2000). Localized damage to coral reefs by tropical storm events (Rogers et al. 1991, Hughes \& Connell 1999), overfishing
(Hughes 1994, Jackson et al. 2001) and pollution from human development and agricultural practices (Szmant 2002) has been exacerbated by regional- and global-scale disturbances including outbreaks of coral predators (Birkeland \& Lucas 1990), disease (Harvell et al. 1999), and climate change (Hoegh-Guldberg 1999). The synergistic effects of these stressors have resulted in broad-scale changes in coral species composition and shifts from coral- to algae-dominated communities (Aronson \& Precht 2000).

Coral-reef communities in the Caribbean have been particularly degraded (Hughes 1994, Bellwood et al. 2004), with an estimated $80 \%$ loss of coral cover over the last 3 decades (Gardner et al. 2003) and little evidence of large-scale recovery (Aronson \& Precht 2001). 
In the 1970 s and 1980 s, the historically-dominant reefbuilding acroporid corals Acropora palmata and A. cervicornis suffered population declines of $>96 \%$ across much of the Caribbean, primarily due to whiteband disease and physical damage from storms (Rogers et al. 1991, Aronson \& Precht 2001). In addition, the Caribbean-wide mass mortality of the herbivorous echinoid Diadema antillarum in the early 1980s (Lessios 1988), combined with reductions in herbivorous fishes due to heavy fish exploitation (Hay 1984), is presumed to have resulted in the widespread proliferation of macroalgae on coral reefs (Carpenter 1990, Hughes 1994). This shift towards macroalgaedominated systems can stress corals, leading to decreased coral survivorship and growth (Knowlton 1992, McCook et al. 2001), and may ultimately lead to coral recruitment failure (Connell et al. 1997) and colony mortality (McCook et al. 2001). Declines in coral populations have been attributed to a number of additional factors including sedimentation (Wolanksi et al. 2003), increased intensity and frequency of coralbleaching events (Hoegh-Guldberg 1999), and an array of diseases (Porter et al. 2001). Coral populations have suffered further damage from corallivorous snails, polychaetes and some fishes (Knowlton et al. 1990), which potentially can cause decreased growth and reduced fecundity and, in extreme cases, colony mortality.

Coral population recovery and persistence depends on successful coral reproduction and recruitment (Richmond 1997, Karlson 1999). Although new colonies can be produced sexually or asexually, sexual reproduction promotes genetic diversity and the dispersal of potentially large numbers of larvae to local and distant reef areas, which is likely to be more important for long-term population recovery and persistence (Richmond 1997). With spawning corals, such as the historically-dominant reef-building Caribbean corals Acropora palmata, A. cervicornis, and Montastrea annularis, reproductive output is largely a function of colony fecundity and population size and density (Knowlton 2001). Colony fecundity is dependent on a coral's size and condition, with sublethal stress and fragmentation resulting in decreased fecundity (Richmond 1997, Lirman 2000). Successful recruitment of corals requires the availability of larvae and appropriate substrate and environmental conditions for larval settlement and survivorship (Richmond 1997). While the presence of turf algae, macroalgae, and cyanobacteria may prevent or inhibit coral settlement (Connell et al. 1997, Kuffner \& Paul 2004), crustose coralline algae (CCA) may promote successful settlement (Morse \& Morse 1996). Additionally, water quality is important for successful reproduction and recruitment, as pollutants and extreme temperatures and salinities can reduce fertilization rates, hinder larval development, inhibit settlement even in the presence of appropriate substrate conditions, and kill newly settled corals (Richmond 1997).

To date, Acropora palmata populations have not recovered from the mass-mortality event of the 1980s to their former abundance across most of the Caribbean (i.e. the US Virgin Islands) (Bruckner 2002). Remaining populations continue to deteriorate due to coral diseases, predators, storms and the other disturbances noted above (Knowlton et al. 1990, Porter et al. 2001, Bruckner 2002). The appearance of new A. palmata recruits in the shallow waters around the US Virgin Islands during the late 1990s (R. GroberDunsmore pers. obs., Garrison \& Rogers pers. comm.) suggests the potential for recovery of this threatened species. However, the broad-scale assessments of $A$. palmata necessary to determine its population status are lacking. The goal of this study was to characterize the population structure of $A$. palmata around the island of St. John, US Virgin Islands, to evaluate its recovery status and to examine the distribution and cooccurrence of stressors that may inhibit population recovery. To provide a baseline for examining changes in A. palmata population structure, we determined the size distribution of populations at 11 sites in 2001 and 2002. In 2003, we resurveyed the A. palmata populations at the 11 baseline sites, and increased our spatial coverage by surveying an additional 18 sites. At each of the resulting 29 sites, we documented the occurrence of potential stressors (Coralliophila abbreviata, damselfish damage, active disease and Hermodice carunculata damage) on individual colonies. The data were examined to address the following questions: (1) Are there spatial and/or demographic patterns to the observed changes in abundance and the distribution of colonies (overall and within various size classes)? (2) Are there spatial and/or demographic patterns to the occurrence of stressors? (3) Do stressors frequently occur together? The findings reported herein provide insights into the recovery status of A. palmata around St. John, US Virgin Islands, and improve our understanding of the factors that may contribute to, or inhibit, its recovery across the broader Caribbean region.

\section{MATERIALS AND METHODS}

Surveys of living Acropora palmata colonies were conducted in August 2001, August 2002, and August and December 2003. A suite of sites was selected to maximize the spatial coverage of shallow, nearshore, hard-bottom habitat around St. John, and to include as many reef areas with historically-dense $A$. palmata 
populations as possible (Fig. 1, Table 1). Survey teams consisted of 2 or 3 snorkelers, who moved parallel to shore at $<5 \mathrm{~m}$ depth, as historically this is where the species was most abundant (Beets et al. 1985). Surveys were conducted along the extent of the hardbottom area, until soft-bottom habitat or some distinguishable physiographic barrier was reached. An exhaustive search of the entire survey area was conducted. To ensure that the same areas were surveyed each year, physical starting and stopping points were indicated on waterproof aerial images (grain size of approximately $3 \mathrm{~m}$; see Kendall et al. 2001) and used as references. These images were imported into Arc View 3.2 (ESRI 1996) and used to estimate the areas of sampled reefs. In areas such as Hawksnest, where colonies were densely distributed, sampled reef areas were divided into smaller, more manageable units using transect tapes to facilitate accurate counts. In 2001 and 2002, the numbers of colonies in each of the following size classes (based on the largest maximum dimension) were recorded at each survey site: $<30 \mathrm{~cm}, 30-70 \mathrm{~cm}, 71-120 \mathrm{~cm}$, 121-200, >200 cm. In 2003, we further divided the smallest size class into 2 categories, branching colonies of $<15 \mathrm{~cm}$ and $15-30 \mathrm{~cm}$ in size. We also combined the 2 largest size classes, as very few corals $(<1 \%)$ exceeded $200 \mathrm{~cm}$ in maximum dimension. Additionally, we noted for each A. palmata colony whether it existed as an unattached fragment (any size) or was encrusting (any size). Furthermore, larger A. palmata colonies that were actually several discrete colonies on the same framework were placed into a size category based on the maximum dimension of living tissue and recorded as remnant/resheeting colonies. Colonies that had suffered partial mortality were sometimes indistinguishable from framework that was being resheeted by new colonies; resheeting is the process of new tissue growth over large areas of dead skeleton and can occur after a colony suffers partial mortality and/or when a sexual propagule recruits to

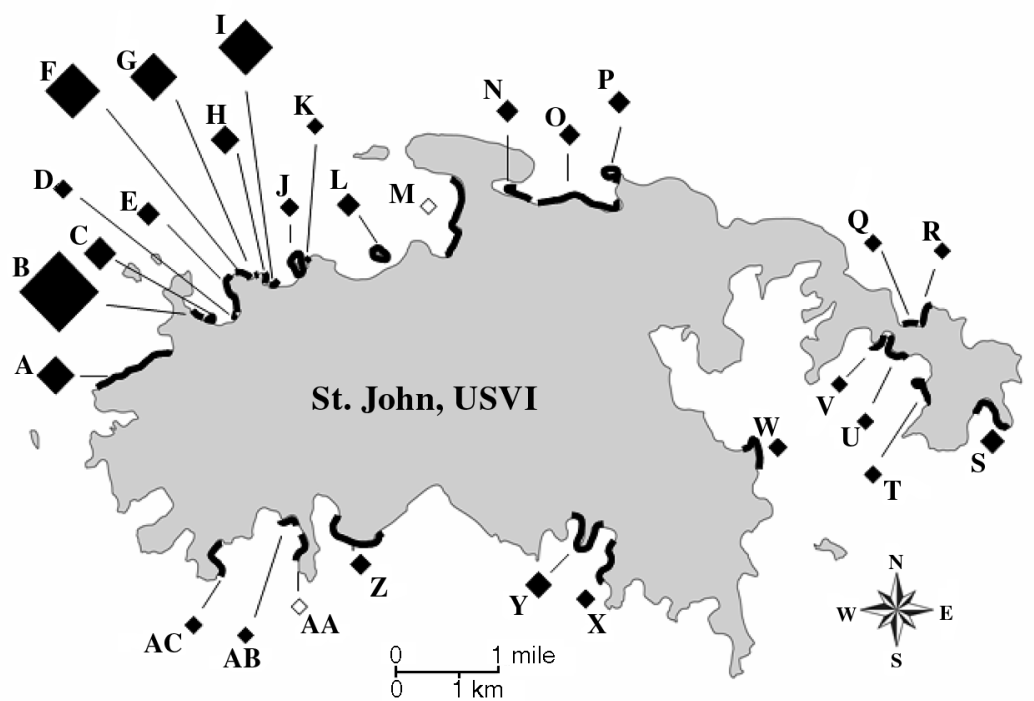

Fig. 1. Spatial distribution of 29 sampling locations along the coast of St. John, US Virgin Islands, in 2003 (site codes as in Table 1) and magnitude of Acropora palmata recruitment (colonies $<15 \mathrm{~cm}$ and encrusting). Size of data points scaled to reflect abundance of recruits; $(\diamond)$ locations where no recruits were observed

Table 1. Acropora palmata. Site code and name, sample area, total number (n) and total density (colonies $\mathrm{m}^{-2}$ ) of colonies, and protection status of 29 sites sampled in 2003. VINP = Virgin Islands National Park; VICRNM = Virgin Islands Coral Reef National Monument; ${ }^{*}$ historically-dense stands based on surveys conducted prior to mass mortality in the 1980s (Beets et al. 1985)

\begin{tabular}{|c|c|c|c|c|c|}
\hline \multirow{2}{*}{$\begin{array}{l}\text { Site } \\
\text { code }\end{array}$} & \multirow{2}{*}{$\begin{array}{l}\text { Site } \\
\text { name }\end{array}$} & \multirow{2}{*}{$\begin{array}{l}\text { Sample area } \\
\qquad\left(\mathrm{m}^{2}\right)\end{array}$} & \multicolumn{2}{|c|}{ Colonies } & \multirow{2}{*}{$\begin{array}{l}\text { Protection } \\
\text { status }\end{array}$} \\
\hline & & & $\mathrm{n}$ & Density & \\
\hline A & Lind Point* & 10562 & 572 & 0.05 & VINP \\
\hline B & Hawksnest (M) ${ }^{*}$ & 6996 & 1996 & 0.28 & VINP \\
\hline $\mathrm{C}$ & Hawksnest (E) ${ }^{*}$ & 3114 & 539 & 0.17 & VINP \\
\hline $\mathrm{D}$ & Gibney Patch* & 2507 & 61 & 0.02 & VINP \\
\hline $\mathrm{E}$ & Gibney & 25189 & 179 & 0.01 & VINP \\
\hline $\mathrm{F}$ & Dennis Bay $(\mathrm{W})^{*}$ & 8339 & 1070 & 0.13 & VINP \\
\hline $\mathrm{G}$ & Dennis Bay $(\mathrm{E})^{*}$ & 4456 & 671 & 0.15 & VINP \\
\hline $\mathrm{H}$ & Jumbie $(\mathrm{W})^{*}$ & 4389 & 277 & 0.63 & VINP \\
\hline I & Jumbie $(\mathrm{E})^{*}$ & 14076 & 810 & 0.06 & VINP \\
\hline $\mathrm{J}$ & Trunk Bay & 13903 & 73 & 0.01 & VINP \\
\hline $\mathrm{K}$ & Trunk Bay-Rafe's* & 3475 & 5 & 0.00 & VINP \\
\hline $\mathrm{L}$ & Cinnamon Cay & 9689 & 139 & 0.01 & VINP \\
\hline M & Francis Bay & 4003 & 2 & $<0.01$ & VINP \\
\hline $\mathrm{N}$ & Mary's Creek* ${ }^{*}$ & 46456 & 218 & 0.01 & VINP \\
\hline $\mathrm{O}$ & Leinster & 63493 & 184 & $<0.01$ & VINP \\
\hline $\mathrm{P}$ & Waterlemon & 8403 & 146 & 0.02 & VINP \\
\hline Q & Haulover Bay $(\mathrm{N})^{*}$ & 12943 & 68 & $<0.01$ & none \\
\hline $\mathrm{R}$ & Haulover Bay $(\mathrm{E})^{*}$ & 12329 & 3 & $<0.01$ & none \\
\hline $\mathrm{S}$ & Privateer ${ }^{*}$ & 38711 & 414 & 0.01 & none \\
\hline $\mathrm{T}$ & Hansen & 22993 & 45 & $<0.01$ & none \\
\hline $\mathrm{U}$ & T-Kai $(\mathrm{N})^{*}$ & 6683 & 9 & $<0.01$ & none \\
\hline $\mathrm{V}$ & T-Kai $(\mathrm{S})^{*}$ & 13797 & 10 & $<0.01$ & VICRNM \\
\hline W & Johnson's Coral Bay* & 154596 & 133 & $<0.01$ & none \\
\hline $\mathrm{X}$ & Donkeybite & 18726 & 83 & $<0.01$ & VINP \\
\hline $\mathrm{Y}$ & Yawzi Point & 29251 & 398 & $<0.01$ & VINP \\
\hline Z & Fish Bay/Coccoloba* & 157680 & 249 & $<0.01$ & VINP \\
\hline AA & Rendezvous & 9882 & 5 & $<0.01$ & none \\
\hline $\mathrm{AB}$ & Klein Bay & 15039 & 6 & $<0.01$ & none \\
\hline $\mathrm{AC}$ & Hart Bay & 38644 & 108 & $<0.01$ & none \\
\hline
\end{tabular}


dead skeletal framework (see Jordán-Dahlgren 1992). Therefore, remnant and resheeting colonies were combined into this remnant/resheeting category.

The presence of corallivorous snails (Coralliophila abbreviata), damselfish damage, active coral disease, and/or polychaete (Hermodice carunculata) damage was recorded for each colony censused in 2003. C. abbreviata was recorded only when present on colonies, and thus the overall extent of damage by this organism may have been underestimated. Damselfish damage was recorded (1) if there were areas of recently-grazed coral polyps colonized by turf algae and actively defended by Stegastes spp. or Microspathodon chrysurus, or (2) when chimney-like structures resulting from prior damselfish damage were present. Scarids, such as Sparisoma viride, can also damage coral tissue. Because of the difficulty in assessing colony damage, damage attributed to damselfishes may sometimes have been the result of scarid predation or scars from previous disease lesions. Active coral disease was recorded if a colony exhibited tissue necrosis and/or active lesions. H. carunculata damage was indicated by feeding scars on branch tips (Knowlton et al. 1990).

Arc View 3.2 (ESRI 1996) was used to visually examine data for temporal and spatial patterns in the distribution of different size classes and stressor frequency, and evaluated based on protection status of the sampled reef areas. The number and size distribution of colonies at the 11 common sites were compared between 2001 and 2003. Data from 2003 for Gibney and Gibney Patch were combined for between-year comparisons because the 2 reef areas were sampled together in 2001. Paired $t$-tests on $\log _{10}$-transformed data were conducted to examine changes in overall abundance between 2001 and 2003 at the 11 baseline sites. We employed a non-parametric, Spearman's rho, correlation analysis to examine the relationship between 2001 population density and the number of new colonies found in 2003 at the 11 baseline sites. Data from 2003 (29 study sites) were analyzed to determine whether stressors differentially affected colonies from different size classes and whether the frequency of stressors covaried. The occurrence of stressors (for all stressors combined and by individual stressor) was compared among size classes using a Kruskal-Wallis non-parametric test. Spearman's rho, multiplecorrelation analysis was conducted to explore correlations between colony density, number of remnants and total number of colonies with Coralliophila abbreviata presence, damselfish damage, active disease and Hermodice carunculata damage. Because multicollinearity was anticipated among these independent variables, several post-hoc tests were applied to verify all relationships. First, partial correlation analysis was con- ducted for all variables. Second, we applied the nonparametric Hoeffding's D-statistic, which is robust against a variety of alternatives to independence, to reduce multicollinearity between colony density and occurrence of individual stressors.

\section{RESULTS}

There was a significant increase in the total number of Acropora palmata colonies at the 11 baseline sites between 2001 and 2003 ( $t=2.28, \mathrm{p}<0.045)$. The abundance of colonies increased at 8 of the 11 baseline sites, with an average site increase of $193 \%( \pm 29 \%$ $\mathrm{SE})$. The greatest increase in new A. palmata colonies from 2001 to 2003 occurred at sites along the northern coastline of the island, with 5 of 7 of these sites having 99 or more new colonies.

In general, the number of colonies in each size class at the 11 baseline sites increased between 2001 and 2003 (Fig. 2); only those colonies in the largest size class, i.e. $>120 \mathrm{~cm}$, did not. Across size classes, colonies in the $<30 \mathrm{~cm}$ size class exhibited the greatest increase $(t=2.54, \mathrm{p}<0.014)$. While there was no statistically significant change in the number of colonies $>120 \mathrm{~cm}$, their abundance remained the same or decreased at 8 of the 11 sites, with an average loss of $48.75 \%( \pm 14.6 \%$ $\mathrm{SE})$, despite the fact that we may have overestimated their abundance in 2003 by classifying remnant colonies using their maximum dimension. No strong spatial pattern was observed related to the loss of colonies $>120 \mathrm{~cm}$; sites around all portions of the island (both inside and outside the Virgin Islands National Park (VINP) and Virgin Islands Coral Reef National Monument (VICRNM)) exhibited losses (Table 1). There was no significant relationship between population density

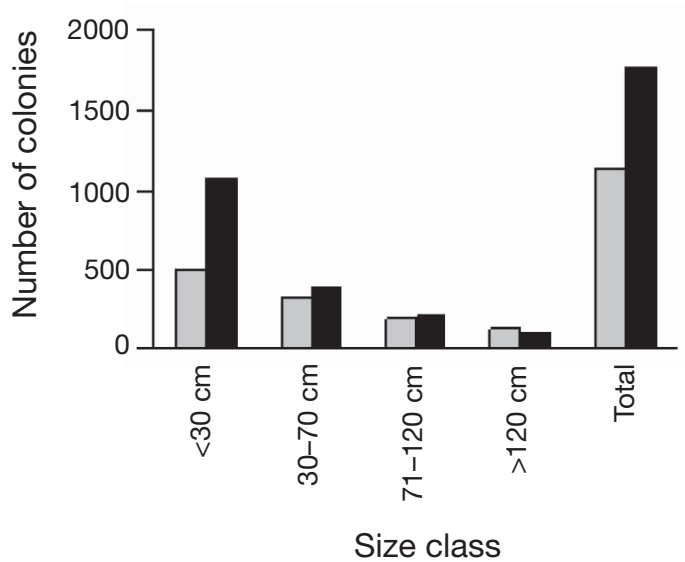

Fig. 2. Acropora palmata. Total abundance of colonies by size class at 11 baseline sites sampled in 2001 (grey bars) and 2003 (black bars) 
in 2001 and the number of new colonies in 2003. Island-wide, $50.24 \%$ (mean percentage of the 29 sites) of the 8491 colonies sampled in 2003 were in the smallest size classes (encrusting, $<15 \mathrm{~cm}$, and 15 to $30 \mathrm{~cm}$ ), while only $4.86 \%$ (mean percentage) of the colonies were $>120 \mathrm{~cm}$ (Fig. 3).

Considering all 29 sites censused in 2003, the greatest abundances and population densities of Acropora palmata occurred along the NW coastline (Fig. 3, Table 1). Survey sites along the NW coast also had the greatest number of potential new recruits $(<15 \mathrm{~cm}$ and encrusting colonies), although recruits were found at most sites surveyed (Fig. 1). These NW sites also generally had more fragments (Fig. 4).

Stressors were documented on coral colonies at most sites around the island, seemingly irrespective of the sites' protective status, i.e. stressors were observed at sites within and outside VINP and VICRNM. Overall, Acropora palmata colonies were most commonly affected by Coralliophila abbreviata (6.1\%) and damselfishes (5.1\%). However, at particular sites, C. abbreviata, damselfish damage and active disease individually affected up to $60.0,44.4$, and $33.3 \%$ of the colonies, re-

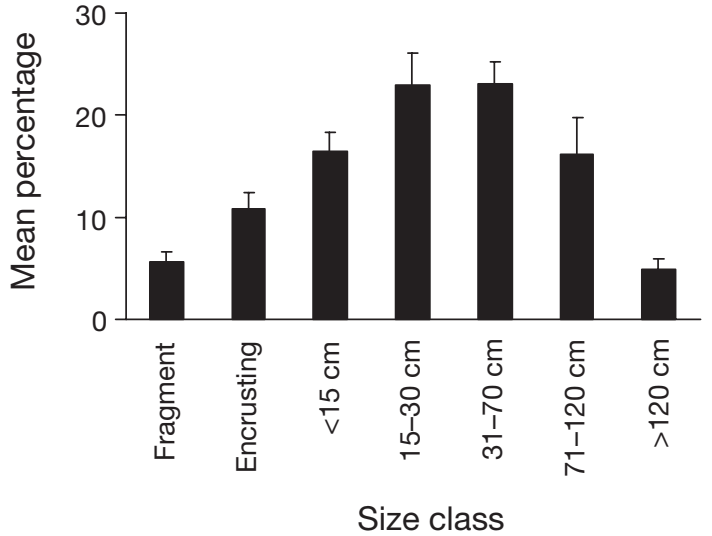

Fig. 3. Acropora palmata. Mean (+SE) percentage of colonies in each size class at 29 sampling locations along the coast of St. John in 2003

spectively. Active disease was observed for only $2 \%$ of the colonies censused in 2003, with symptoms generally consistent with those of white pox, which is characterized by tissue degradation in circular lesions.
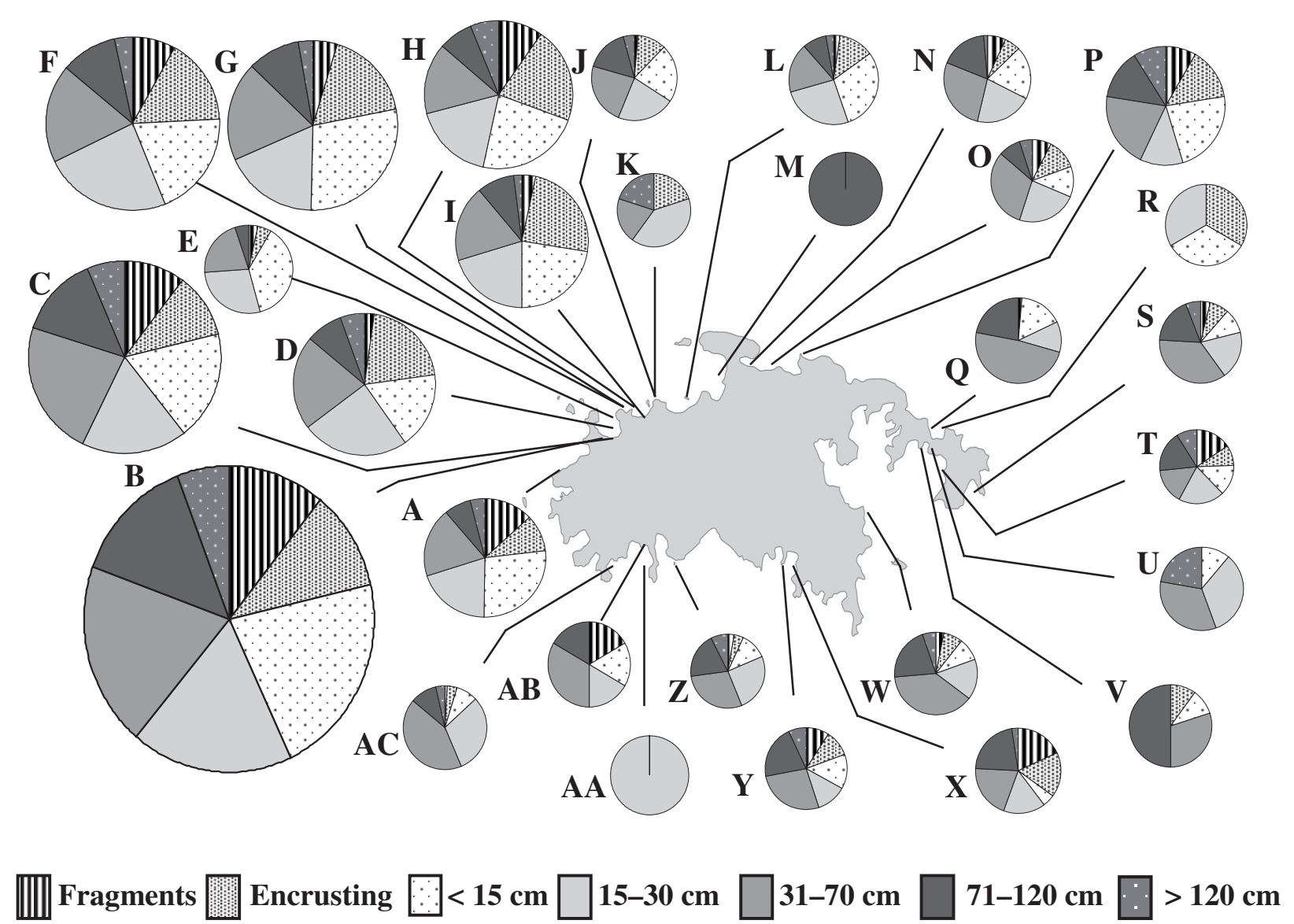

Fig. 4. Acropora palmata. Size distribution for each of 7 size classes of colonies at 29 sampling locations along the coast of St. John in 2003 (site codes as in Table 1). Pie-chart size scaled to reflect total density of colonies 

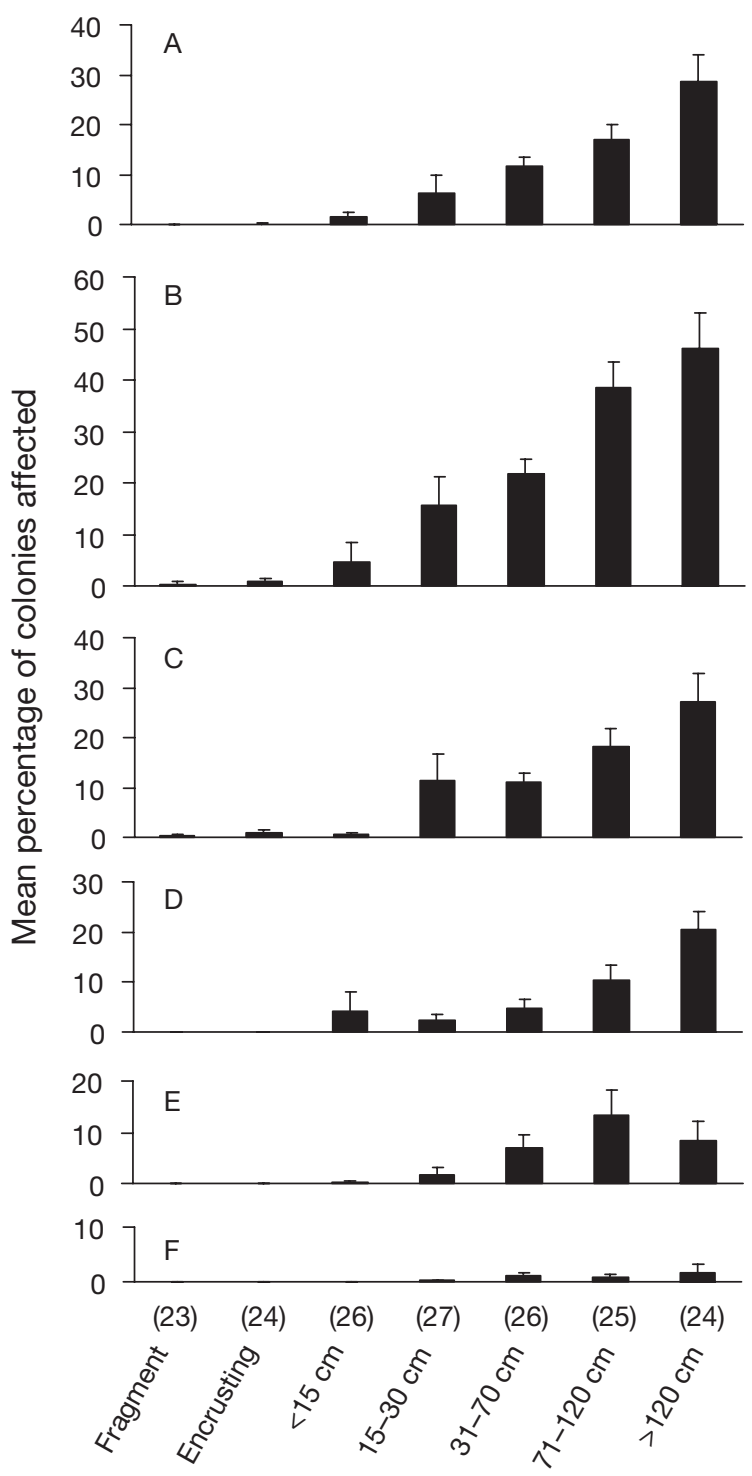

Size class

Fig. 5. Acropora palmata. Mean (+SE) percentage of colonies in each size class that are (A) remnants, or are affected by (B) 1 or more stressors, (C) Coralliophila abbreviata, (D) damselfish damage, (E) active disease, or (F) Hermodice carunculata damage. $\mathrm{N}$ (number of sites) given in parentheses for each size class

Significant differences in the percentage of colonies affected by at least 1 stressor were found among different size classes of corals (Kruskal-Wallis test, p < 0.0001) (Fig. 5), with small colonies less frequently affected by stressors (Kruskal-Wallis test, p < 0.0001). Stressors most frequently affected colonies $>120 \mathrm{~cm}$ (46.1\% were affected by at least one stressor) (Fig. 5B), although colonies in this largest size class, as stated previously, were not common (Fig. 3).
In addition, larger colonies were significantly more likely to be remnants (Kruskal-Wallis test, $\mathrm{p}<0.0001$ ). In fact, $28.8 \%$ of colonies $>120 \mathrm{~cm}$ were classified as such (see Fig. 5A).

The percentage of the largest colonies affected by any individual stressor was significantly greater than that of the smallest colonies (Kruskal-Wallis, $\mathrm{p}<0.0001$ for Coralliophila abbreviata, damselfish damage and active disease, and $\mathrm{p}<0.02$ for Hermodice carunculata damage) (Fig. 5). On average, $>27 \%$ of colonies $>120 \mathrm{~cm}$ at each of the 29 sites had C. abbreviata present (Fig. 5C), and $>20 \%$ of colonies $>120 \mathrm{~cm}$ at each of these same sites exhibited signs of damselfish damage (Fig. 5D). H. carunculata damage was rarely observed on corals of any size class $(0.06 \%$ overall), although the greatest mean percent occurrence (1.6\%) was on colonies of 70 to $120 \mathrm{~cm}$ (Fig. 5F). The incidence of $C$. abbreviata, damselfish damage and active disease was ubiquitous around the island; they occurred at $89.7,72.4$, and $75.9 \%$ of the sites, respectively, and did not appear to be related to protection status.

There were significant positive correlations between stand density and the abundance of colonies with Coralliophila abbreviata and damselfish damage, and these remained significant after the post-hoc tests (partial correlation analysis and Hoeffding's D) were applied (Table 2). The abundance of colonies with active disease or Hermodice carunculata damage, however, was not significantly correlated with stand density, following the application of post-hoc tests (Table 2). Remnant colonies (regardless of size) were strongly associated with individual stressors (KruskalWallis, $\mathrm{p}<0.0001)$. There were significant correlations for all combinations of stressors (Table 2). The number of remnant colonies was strongly and significantly correlated with the presence of C. abbreviata $\left(\mathrm{R}^{2}=0.83\right.$, $\mathrm{p}<0.0001)$ and active disease $\left(\mathrm{R}^{2}=0.61, \mathrm{p}<0.0004\right)$, and these relationships remained significant after the post-hoc tests were applied (Table 2). There was no significant relationship between remnant colonies and damselfish damage after post-hoc tests were applied (Table 2). There was, however, a strong significant association between damselfish damage and active disease that remained significant following post-hoc analyses (Table 2).

\section{DISCUSSION}

Acropora palmata populations around the island of St. John show signs of recovery, as evidenced by the significant increase in total abundance of colonies and abundance of new recruits from 2001 to 2003 at sites distributed around the island. Our observations and size-class data suggest that recruitment of new 
Table 2. Spearman's rank pairwise comparisons and partial correlation analysis of relationships of stand density and stressors affecting Acropora palmata in 2003. Relationships in bold have significant Hoeffding's $D$-statistic

\begin{tabular}{|lcrr|}
\hline Stressor relationship & Spearman's R & p-value & Partial r \\
\hline Coralliophila abbreviata and stand density & $\mathbf{0 . 8 2}$ & $<\mathbf{0 . 0 0 0 1}$ & $\mathbf{0 . 4 6}$ \\
Damselfish damage and stand density & $\mathbf{0 . 8 7}$ & $<\mathbf{0 . 0 0 0 1}$ & $\mathbf{- 0 . 1 2}$ \\
Active disease and stand density & 0.67 & $<0.0001$ & 0.19 \\
Hermodice carunculata and stand density & 0.19 & $<0.0103$ & -0.42 \\
Damselfish damage and C. abbreviata & 0.79 & $<0.0001$ & 0.66 \\
Active disease and C. abbreviata & 0.61 & 0.0006 & -0.13 \\
H. carunculata and C. abbreviata & 0.55 & 0.0020 & 0.05 \\
Active disease and damselfish damage & $\mathbf{0 . 6 4}$ & $\mathbf{0 . 0 0 0 2}$ & $\mathbf{0 . 1 3}$ \\
Active disease and H. carunculata & 0.35 & 0.0690 & 0.01 \\
Remnant and C. abbreviata & $\mathbf{0 . 8 3}$ & $<\mathbf{0 . 0 0 0 1}$ & $\mathbf{0 . 5 4}$ \\
Remnant and damselfish damage & 0.76 & $<0.0001$ & -0.46 \\
Remnant and active disease & $\mathbf{0 . 6 1}$ & $\mathbf{0 . 0 0 0 4}$ & $\mathbf{0 . 5 8}$ \\
Remnant and H. carunculata & 0.66 & $<0.0001$ & 0.06 \\
\hline
\end{tabular}

distant or local populations. Additionally, reefs along the NW coast may have substrates that are more conducive for coral settlement and survivorship, or fragmentation may occur more frequently (as indicated by the relatively high number of fragments recorded at these sites) as a consequence of their exposure (i.e. high wave energy) and high visitation rates (i.e. snorkler/diver activity). Our findings suggest that some combination of factors (e.g. wave exposure, substrate conditions, larval supply) contributes to the NW coastline being better suited than other areas of the island to successful recruitment of A. palmata. These factors may act at varying scales, as sug-

colonies probably began in the late 1990s and has continued through 2003, which is temporally consistent with observations of high densities of new, small colonies $(<15 \mathrm{~cm})$ in many locations in the Caribbean including Buck Island, St. Croix, the Dominican Republic, the Northern Yucatan, Los Roques Islands and Puerto Rico (Bruckner 2002, Zubillaga et al. 2005). In combination, these findings are suggestive of a broad recovery potential for $A$. palmata, in spite of the longer-term pattern of coral reef degradation within the Caribbean region (Gardner et al. 2003, Pandolfi et al. 2003).

The distribution pattern of abundance of Acropora palmata in the shallow waters around the island of St. John indicates not only that the highest overall densities occur along the NW shoreline, but that new recruits are also more common there. This latter finding is particularly interesting given that study reefs in the NW area were generally amongst the smallest sampled. This NW bias is consistent when examining the state of historically-dense stands (Beets et al. 1985); those in the NW have the greatest abundance, density and number of new recruits in 2003, while those on the northern, eastern and southern coastlines have lower abundances and densities of colonies and fewer recruits despite their relatively larger reef areas. Reefs along the NW coast may be well situated to receive and retain coral larvae from either local or distant sources. Dense relict populations of A. palmata (those that may have survived the mass mortality of the 1980s), which potentially generate large numbers of larvae, were recently observed at some up-current locations in the British Virgin Islands, such as Virgin Gorda and Anegada (R. Grober-Dunsmore pers. obs.). Large and meso-scale eddies and meanders that move north from the Lesser Antilles across the British and US Virgin Islands may transport coral larvae generated by gested by the between-site differences in the number of recruits, thus potentially explaining the considerable variation observed in the individual trajectories of coral communities (Edmunds 2002).

Several demographic patterns associated with the change in colony abundance documented between 2001 and 2003 and the size distribution of colonies at the 29 study sites surveyed in 2003 provide insights into the factors that are likely to control recovery of Acropora palmata around St. John. First, $>50 \%$ of the colonies sampled in 2003 were $<30 \mathrm{~cm}$ in size or encrusting, suggestive of successful recruitment events over the past 4 to $7 \mathrm{yr}$. Moreover, a large number of these colonies (ca. $33 \%$ ) were $<15 \mathrm{~cm}$ or encrusting, which, based on our observations, is indicative of sexually produced recruits rather than fragments or partial colony-mortality. Historically, fragmentation was considered by some workers to be a primary mode of propagation for A. palmata (e.g. Bak \& Engel 1979), and while it undoubtedly contributed to the increased abundance of colonies in this study, sexual recruitment appears, at present, to be more prevalent. Consistent with this view are the findings of Baums et al. (2005), who found $52.3 \%$ of the colonies (mean for 3 reefs) sampled in St. John were unique genets; however, this is a conservative estimate, and we suspect this number might have been substantially greater if sampling had been restricted to small colonies. Furthermore, we note that the lack of a density-dependent relationship between colony density in 2001 and the number of subsequent new recruits corroborates findings from other coral studies, indicating that the current state of the local population may not predict future population dynamics (Edmunds 2002). Finally, while the population size-distribution in St. John is indicative of a recovering population, the loss of larger colonies suggests that conditions are not conducive for survival and 
ultimately recovery to historic population levels and stand structure.

Stressors were observed at sites distributed around the island, with no apparent spatial pattern to their occurrence. Local protective status provided by the VINP and VICRNM appears insufficient to reduce the incidence of stressors. Sites along the NW coast have the highest abundances and densities of colonies, and all occur within the boundaries of VINP. Additional protective measures (e.g. limited snorkeler access and reduced fishing pressure) may be necessary to facilitate recovery of this threatened species.

Although stressor occurrence was highly variable among sites, the overall incidence was generally less than that reported from other parts of the Caribbean. Overall, Coralliophila abbreviata were present on $6.1 \%$ of our sampled colonies, compared with $18 \%$ in Puerto Rico (Bruckner et al. 1997) and 10 to $20 \%$ in the Florida Keys (Baums et al. 2003). Damselfish damage was evident on $5.1 \%$ of our sampled colonies overall, which is far below the $70 \%$ reported for the Florida Keys (Bruckner 2002) and the $56 \%$ reported for Colombia (Bruckner 2002), although the proportion of colonies affected at several reefs approached these values. Predation by Hermodice carunculata was generally low and comparable to gross estimates of $<0.1 \%$ on A. palmata fragments in Puerto Rico (Bruckner 2002). Although comparable at the scale of individual reefs, the $2 \%$ occurrence of active disease we found on colonies overall was lower than the $18 \%$ reported for individual reefs in Colombia (Bruckner 2002) and the $70 \%$ detected in St. John by Rogers et al. (2005). Our lower frequencies for some stressors compared to other studies may be partially explained by spatial-scale differences in sampling (individual reef versus islandwide sampling). Furthermore, most studies are conducted to address outbreak conditions rather than to characterize background conditions, and historical data on stressor occurrence are sorely lacking.

Of particular concern for the recovery of Acropora palmata is our finding that stressors disproportionately affected larger colonies. This may be partly due to an area effect, as larger colonies are not only likely to offer better refuge for organisms such as Coralliophila abbreviata and damselfishes than smaller colonies, but also have a greater surface area that can be affected by a stressor. However, the morphology of A. palmata and limitations of our sampling technique preclude our ability to sufficiently address this issue. Larger colonies were also more likely to be remnants, which is an indication of stress-related tissue loss. Although large colonies in general exhibit greater fecundity (Richmond 1997) and fragmentation potential than small colonies, high stressor frequency on large colonies is likely to reduce their reproductive output (Richmond
1997). If chronic multiple stressors, such as those recorded in this study, preferentially affect larger colonies, they may severely limit the regenerative capacity of coral populations.

Of additional concern is that relict framework (dead colonies that remain in the growth position) is being recolonized. Colonies, which appear to be sexual recruits, are encrusting the framework in a process called resheeting. While this may allow colonies to attain a large size rather quickly, thus rapidly increasing coral cover, the longer-term structural integrity of these resheeted colonies is likely to be compromised (Bonito \& Grober-Dunsmore 2005). We observed that relict framework, much of which has remained devoid of corals for over $20 \mathrm{yr}$, is often heavily colonized by bioeroders. Bioeroders can weaken the structural integrity of the framework, leaving colonies resheeting it, and growing on it, more susceptible to physical disturbance.

The occurrence of 2 stressors (Coralliophila abbreviata and damselfish damage) on individual Acropora palmata colonies was greater in high-density stands, suggesting a density-dependent relationship. Interestingly, this was not the case for active disease or Hermodice carunculata damage. Although the incidence of active disease around St. John was generally low, and only weakly associated with stand density, disease may persist as a chronic stress that is present at some background level in all populations (see also Rogers et al. 2005), or be transported either passively through the water column or by some biological vector among and within A. palmata populations. Epidemiological data on white pox and other coral diseases in the Caribbean (Porter et al. 2001) is scarce (but see Patterson et al. 2002), but is essential if we are to more fully understand the etiology of coral diseases and their potential effects on the recovery of $A$. palmata populations.

The occurrence of multiple stressors on coral colonies may result in complex and non-additive effects that hinder coral population recovery. In particular, Coralliophila abbreviata may cause substantial tissue loss, thus contributing to the high number of remnant Acropora palmata colonies. Although snail predation rarely caused colony mortality at a site in Haulover Bay, St. John (C. S. Rogers pers. comm.), and did not cause extensive damage to corals in Barbados (Ott \& Lewis 1972), our findings corroborate findings from Jamaica (Knowlton et al. 1990) and the Florida Keys (Baums et al. 2003) that suggest $C$. abbreviata can cause considerable damage to A. palmata populations. In addition, territorial damselfishes could play a role in the establishment and/or transmission of active disease, particularly in reef areas with high abundances of A. palmata. Damselfishes bite repeatedly at the same location, removing coral polyps and creating conspicuous lesions (Kaufman 1977) that may then be 
infected by pathogens present in the water column. Furthermore, damselfishes may spread disease through their mouths or feces. Some studies suggested that coral-damaging organisms can serve as vectors of disease (Sussman et al. 2003), including several that suggested a causal link between corallivorous snails and disease (Bruckner et al. 1997), yet there has been little experimental research addressing this possibility. Disease, in turn, appears to contribute to partial mortality of colonies, possibly contributing to the high abundance of remnant colonies, as suggested by Patterson et al. (2002). While our data merely suggest a relationship between the presence of damselfish damage (and to a lesser extent $C$. abbreviata) and active disease, experimental manipulations are clearly required to tease apart the complex interactions between stand density, colony size, damselfishes, coral predators and disease transmission.

Although Acropora palmata populations in St. John are exhibiting signs of recovery, with potential new recruits and increases in the total number of colonies at most of our study sites, the prognosis for eventual recovery to historic conditions is uncertain. Of concern is the lack of survival of larger colonies, which are most affected by stressors; larger colonies have greater reproductive potential, and their loss may have disproportional consequences for population recovery and persistence. Protective actions taken in the Virgin Islands (i.e. VINP, VICRNM) appear ineffective in shielding corals from the observed stressors, as stressors were present around the entire island. Furthermore, the structural integrity of resheeting colonies may be compromised by bioeroders, which may have colonized relict framework, making them more susceptible to physical disturbances. A number of complex relationships exist between stand density and stressor occurrence (e.g. stand density and Coralliophila abbreviata) and among individual stressors (e.g. damselfishes and disease). Although these relationships are difficult to verify based on the correlative nature of this study, they provide hypotheses that merit testing. Experimental studies are clearly needed on the duration and frequency of exposure of colonies to these and other stressors in order to better understand the long-term effects of chronic, multiple stressors on A. palmata populations.

Disturbance is an integral part of coral community dynamics and can have lasting effects on coral community structure (Karlson 1999), but the response of coral communities to disturbance events will depend on the size, intensity and the frequency of disturbance as well as the tolerance and life histories of the resident species (Connell \& Keough 1985). It is poorly understood to what extent human activities have shifted environmental conditions (increased temperature, sedimenta- tion, predator removal), potentially creating more conducive conditions for the proliferation of biological stressors. Understanding the compound effects and interactions of current disturbance regimes and global climate change is one of our most pressing ecological challenges for understanding the fate of coral reef communities (Hughes et al. 2003). Although the apparent return of Diadema populations in some Caribbean locations may appear promising for coral community recovery (Edmunds \& Carpenter 2001), we can only speculate whether or not acroporids will recover, given current levels of protection, the ephemeral nature of ecological disturbances inherent throughout their range, and their susceptibility to local, regional and global sources of mortality.

Acknowledgements. Funding provided by Disney Wildlife Conservation Fund and the Canon National Parks Science Scholars Program. We greatly appreciate the support of the Biological Resources Division of the USGS and Virgin Islands National Park. Data were collected with the assistance of I. Kuffner (2003), T. K. Dunsmore (2001-2003), T. Kelley (2001), S. Caseau (2001), J. Hale (2001), and J. Hopkins (2001). We thank R. Boulon (NPS), C. Rogers (USGS), B. Devine (UVI), E. Muller (FIT) and C. Loomis (NPS) for discussions regarding the data and its relevance to their longerterm and ongoing studies. We thank G. Paulay, I. Kuffner, and G. Garrison for comments on earlier manuscript drafts.

\section{LITERATURE CITED}

Aronson RB, Precht WF (2000) Herbivory and algal dynamics on the coral reef at Discovery Bay, Jamaica. Limnol Oceanogr 45:251-255

Aronson RB, Precht WF (2001) White-band disease and the changing face of Caribbean coral reefs. Hydrobiologia 460:25-38

Bak RPM, Engel MS (1979) Distribution, abundance, and survival of juvenile hermatypic corals (Scleractinia) and the importance of life history strategies in the parent community. Mar Biol 54:341-352

Baums IB, Miller MW, Szmant AM (2003) Ecology of a corallivorous gastropod, Coralliophila abbreviata, on two scleractinian hosts. I. Population structure of snails on corals. Mar Biol 142:1083-1091

Baums IB, Miller MW, Hellberg ME (2005) Regionally isolated populations of an imperiled Caribbean coral, Acropora palmata. Mol Ecol 14:1377-1390

Beets J, Lewand L, Zullo ES (1985) Marine community descriptions and maps of bays within the Virgin Islands National Park/Biosphere Reserve. Biosphere Reserve Res Rep 2 VIRCM/NPS

Bellwood DR, Hughes TP, Folke C, Nyström M (2004) Confronting the coral reef crisis. Nature 429:827-833

Birkeland CE, Lucas JS (1990) Acanthaster planci: major management problem of coral reefs. CRC Press, Boston, MA

Bonito V, Grober-Dunsmore R (2005) Resheeting of relict Acropora palmata framework may promote fast growth, but does it compromise the structural integrity of the colony? Coral Reefs (on-line edition)

Bruckner AW (2002) Proceedings of the Caribbean Acropora Workshop: potential application of the US Endangered 
Species Act as a conservation strategy. NOAA Tech Memo NMFS OPR-24

Bruckner RJ, Bruckner AW, Williams EH Jr (1997) Life history strategies of Coralliophila abbreviata Lamarck (Gastropoda: Coralliophilidae) on the southwest coast of Puerto Rico. Proc 8th Int Coral Reef Symp 1:627-632

Carpenter RC (1990) Mass mortality of Diadema antillarum. 1. Long-term effects on sea urchin population-dynamics and coral reef algal communities. Mar Biol 104:67-77

Connell JH, Keough MJ (1985) Disturbance and patch dynamics of subtidal marine animals on hard substrata. In: Pickett STA, White PS (eds) the ecology of natural disturbance and patch dynamics. Academic Press, New York, p 125-151

Connell JH, Hughes TP, Wallace CC (1997) A 30-year study of coral abundance, recruitment, and disturbance at several scales in space and time. Ecol Monogr 67:461-488

Edmunds PJ (2002) Long-term dynamics of coral reefs in St. John, US Virgin Islands. Coral Reefs 21:357-367

Edmunds PJ, Carpenter RC (2001) Recovery of Diadema antillarum reduces macroalgal cover and increases abundance of juvenile corals on a Caribbean reef. Proc Natl Acad Sci USA 98:5067-5071

ESRI (Environmental Systems Research Institute) (1996) Arc view spatial analyst. Redlands, CA

Gardner TA, Cote IM, Gill JA, Grant A, Watkinson AR (2003) Long-term region-wide declines in Caribbean corals. Science 301:958-960

Harvell CD, Kim K, Burkholder JM, Colwell RR and 9 others (1999) Review: marine ecology-emerging marine diseases - climate links and anthropogenic factors. Science 285:1505-1510

Hay ME (1984) Patterns of fish and urchin grazing on Caribbean coral reefs-are previous results typical? Ecology 65:446-454

Hoegh-Guldberg O (1999) Climate change, coral bleaching and the future of the world's coral reefs. Mar Freshw Res 50:839-866

Hughes TP (1994) Catastrophes, phase-shifts and large-scale degradation of a Caribbean coral reef. Science 265: $1547-1551$

Hughes TP, Connell JH (1999) Multiple stressors on coral reefs: a long-term perspective. Limnol Oceanogr 44:932-940

Hughes TP, Baird AH, Bellwood DR, Card M and 13 others (2003) Climate change, human impacts, and the resilience of coral reefs. Science 301:929-933

Jackson JBC, Kirby MX, Berger WH, Bjorndal KA and 15 others (2001) Historical overfishing and the recent collapse of coastal ecosystems. Science 293:629-638

Jordán-Dahlgren E (1992) Recolonization patterns of Acropora palmata in a marginal environment. Bull Mar Sci 51: 104-117

Karlson RH (1999) Dynamics of coral communities. Kluwer Academic, Boston, MA, p 140-164

Kaufman LS (1977) The threespot damselfish: effects on benthic biota of Caribbean coral reefs. Proc 3rd Int Coral Reef Symp 1:559-564

Kendall MS, Kruer CR, Buja KR, Christensen JD, Finkbeiner M, Monaco ME (2001) Methods used to map the benthic habitats of Puerto Rico and the US Virgin Islands. NOAA Tech Memo NOS NCCOS CCMA 152

Knowlton N (1992) Thresholds and multiple stable states in coral-reef community dynamics. Am Zool 32:674-682

Editorial responsibility: Ron Karlson (Contributing Editor), Newark, Delaware, USA
Knowlton N (2001) The future of coral reefs. Proc Natl Acad Sci USA 98:5419-5425

Knowlton N, Lang JC, Keller BD (1990) Case study of natural population collapse: post-hurricane predation on Jamaican staghorn corals. Smithson Contrib Mar Sci 31:1-25

Kuffner IB, Paul VJ (2004) Effects of the benthic cyanobacterium Lyngbya majuscula on larval recruitment of the reef corals Acropora surculosa and Pocillopora damicornis. Coral Reefs 23:455-458

Lessios HA (1988) Mass mortality of Diadema antillarum in the Caribbean - what have we learned? Annu Rev Ecol Syst 19:371-393

Lirman D (2000) Fragmentation in the branching coral Acropora palmata (Lamarck): growth, survivorship, and reproduction of colonies and fragments. J Exp Mar Biol Ecol 251:41-57

McCook LJ, Jompa J, Diaz-Pulido G (2001) Competition between corals and algae on coral reefs: a review of evidence and mechanisms. Coral Reefs 19:400-417

Morse ANC, Morse DE (1996) Flypapers for coral and other planktonic larvae. BioScience 46:254-262

Nyström M, Folke C, Moberg F (2000) Coral reef disturbance and resilience in a human-dominated environment. Trends Ecol Evol 15:413-417

Ott B, Lewis JB (1972) The importance of the gastropod Coralliophila abbreviata (Lamarck) and the polychaete Hermodice carunculata (Pallas) as coral reef predators. Can J Zool 50:1651-1656

Pandolfi JM, Bradbury RH, Sala E, Hughes TP and 8 others (2003) Global trajectories of the long-term decline of coral reef ecosystems. Science 301:955-958

Patterson KL, Porter JW, Ritchie KB, Polson SW, Mueller E, Peters EC, Santavy DL, Smith GW (2002) The etiology of white pox, a lethal disease of the Caribbean elkhorn coral, Acropora palmata. Proc Natl Acad Sci USA 99:8725-8730

Porter JW, Dustan P, Jaap WC, Patterson KL, Kosmynin V, Meier OW, Patterson ME, Parsons M (2001) Patterns of spread of coral disease in the Florida Keys. Hydrobiologia 460:1-24

Richmond RH (1997) Reproduction and recruitment in corals: critical links in the persistence of reefs. In: Birkeland C (ed) Life and death of coral reefs. Chapman \& Hall, New York, p 175-197

Rogers CS, Mclain LN, Tobias CR (1991) Effects of Hurricane Hugo (1989) on a coral reef in St. John, USVI. Mar Ecol Prog Ser 78:189-199

Rogers CS, Sutherland KP, Porter JW (2005) Has white pox disease been affecting Acropora palmata for over 30 years? Coral Reefs 24:194

Sussman M, Loya Y, Fine M, Rosenberg E (2003) The marine fireworm Hermodice carunculata is a winter reservoir and spring-summer vector for the coral-bleaching pathogen Vibrio shiloi. Environ Microbiol 5:250-255

Szmant AM (2002) Nutrient enrichment on coral reefs: is it a major cause of coral reef decline? Estuaries 25:743-766

Wolanski E, Richmond R, McCook L, Sweatman H (2003) Mud, marine snow and coral reefs - the survival of coral reefs requires integrated watershed-based management activities and marine conservation. Am Sci 91:44-51

Zubillaga AL, Bastidas C, Croquer A (2005) High densities of the elkhorn coral Acropora palmata in Cayo de Agua, Archipelago Los Roques National Park, Venezuela. Coral Reefs 24:86-86

Submitted: May 25, 2005; Accepted: November 17, 2005

Proofs received from author(s): August 23, 2006 